\title{
An assessment of the \\ Causes of Lead Pollution and \\ the Efficiency of Bioremediation \\ by Plants and Microorganisms
}

\author{
Naofumi Shiomi \\ Additional information is available at the end of the chapter \\ http://dx.doi.org/10.5772/60802
}

\begin{abstract}
A rapid increase in mining industries associated with an increase in lead demand has resulted in the problem of lead poisoning. In this study, the initial causes of lead pollution were investigated. The results suggest that soil pollution from lead did not occur in urban and agricultural areas due to the efforts of decreased lead use and an increase in recycling; however, serious pollution locally occurred in the areas where metallurgy and mining industries were present. Therefore, remediation must be carried out in the latter areas. Next, the efficiency of lead remediation by plants and microorganisms in the areas with increased lead pollution was assessed. The plants showing high potential have been developed, and phytoextraction is a promising process. However, a more cost-effective method is necessary to achieve widespread implementation. Thus, a novel remediation method (the landfarming with immobilized microorganisms (LIM) method) to overcome the problem of cost was proposed. The LIM method combines the immobilized technique with landfarming. As the treatment period is short and the lead can readily be recycled from the soil, the LIM method may be a better alternative to phytoextraction for lead remediation.
\end{abstract}

Keywords: Lead, Phytoextraction, Bioremediation, Landfarming 


\section{Introduction}

Pollution by heavy metals has gradually worsened in Asian, African, and South American countries, partly due to the excessive use of pesticides for growing crops which may in turn lead to the pollution of groundwater and well water. An investigation by the Food and Agriculture Organization (FAO)/United Nations Environment Programme (UNEP)/World Health Organization (WHO) suggests that the number of patients with pesticide poisoning is approximately 1-5 million annually, and several thousand cases are fatal. In some Asian countries, wells reserved for drinking water were dug below the acceptable levels to avoid pesticide pollution, and consequently, many inhabitants developed arsenic poisoning [1, 2]. Rivers and soils are also polluted by industrial wastes in those countries. In particular, wastes from metallurgy and mining industries contain various heavy metal ions, and wastes from leather industries contain cadmium and chromium. These wastes are typically exhausted and discarded in nearby rivers and in the air due to the lack of posttreatment equipment or strictly controlled landfill sites, resulting in detrimental groundwater and soil pollution.

Additionally, environmental pollution by heavy metals has resulted in serious disease. In Japan, four historic cases of metal pollution occurring predominately in the 1950s have been reported, which include "ouch-ouch" disease and Minamata disease. In 1910, a mining company eliminated cadmium waste into a nearby river. The inhabitants who drank directly from the river or ingested food grown along the riverbanks developed cadmium poisoning and exhibited symptoms such as spine and leg pain and fragile bones. In another case of heavy metal poisoning, the improper elimination of methylmercury waste into a nearby river resulted in neuroparalysis (Minamata disease) among the locals. Recent problems due to heavy metal pollution in some countries may be more serious than the previous incidences in Japan. Therefore, it is critical to remediate polluted areas as quickly as possible in order to decrease the risk of disease.

Lead is an important heavy metal because it is widely used to produce electronics, crystal glasses, and batteries. The annual consumption of lead has been increasing at a high rate in China due to the increased demand for cars and power-assisted bicycles according to the rapid economic growth. Recently, a relationship between high blood lead levels and lead pollution in lead mining areas has been proclaimed as a serious problem [3]. Some reports have suggested that many children living in the areas near mining industries developed symptoms of lead poisoning [4]. Therefore, the control of lead emissions and remediation of soil polluted from lead are crucial.

The purpose of this chapter is to assess both the causes of lead pollution and the efficiency of bioremediation by plants and microorganisms. First, the author investigated the causes of lead contamination, and the results suggest that soil pollution from lead occurred particularly in the areas where metallurgy and mining industries were present. Then, the author determined whether phytoextraction is a practical method for lead remediation in these areas. Finally, the author proposed a novel lead remediation process which employs microorganisms. The proposed process, the LIM method, combines immobilization with landfarming. As the 
treatment period in the LIM method is much shorter and lead can be readily collected from the soil, the process may be a viable alternative to phytoextraction.

\section{Assessment of the causes of lead pollution}

\subsection{History of lead use}

Lead has been utilized in the production of many products, such as tableware, tubes, and pipes, since the age of Ancient Rome [5] because it can be easily manipulated due to its low melting point and malleability. However, lead poisoning has gradually increased since the 1970s. One major source of lead poisoning has been gasoline. Gasoline containing tetraethyl lead or tetramethyl lead (lead gasoline) was widely utilized to protect car engines. A significant amount of volatile organic lead exhausted by cars triggered air and soil pollution, resulting in the symptoms of lead poisoning. In Japan, the soil near the roads in large cities contained 10 $30 \mathrm{~g} / \mathrm{kg}$ of lead. To remedy this problem, alkylate gasoline was developed and regular and high-octane gasolines were changed to lead-free gasoline in 1975 and 1987, respectively, in Japan. The United States banned lead gasoline sales in 1995 in accordance with the Clean Air Act, and EU banned lead gasoline in 2000. Many other countries (more than 50) have banned or decreased the amount of lead in gasoline [6]. Another major source of lead poisoning was water contamination due to lead pipes. Lead pipes have been used to transport tap water in many countries and were used as service pipes for tap water until the 1970s in Japan. In Uruguay, for example, the inhabitants of old houses had elevated blood lead levels, because most of the old houses used lead pipes for tap water [7]. The dangers of lead poisoning from lead pipes are well recognized, and the use of lead is being reconsidered.

The use of lead in 1996 and 2009 in Japan is depicted in Figure 1A [8]. More than $80 \%$ of lead is utilized for the production of lead-acid batteries for cars and industries. The second most common use is in inorganic chemicals, such as a polyvinyl chloride stabilizer, crystal glass, and paint. A polyvinyl chloride stabilizer containing lead was widely used due to its protective effects in the elimination reaction of vinyl chloride by oxygen. Crystal glass, which contains a high concentration of lead(II) oxide ( $\mathrm{PbO})$, is also widely used due to its high degree of transparency and refractive index, similar to crystal. Other common uses for lead include solder for electronic materials, tubes for draining and exhausting, and plates for medical equipment and lagging materials of underground cable. Moreover, lead production is rapidly increasing in some countries due to an increase in the production of lead-acid batteries, especially in China (Fig. 1B) [9].

\subsection{Emission control of lead in Japan and other countries}

Heavy metal pollution has become an increasing concern in the EU [10]. The amount of waste of electrical and electronic equipment (WEEE) in 2005 was approximately 9 million tons and is steadily increasing at a rate of $5 \%$ annually. The wastes are generally burned or buried without any treatment. If the total amount is calculated based on the assumption that WEEE contains approximately $5 \%$ solder, 22, 500 tons of lead is lost as waste every year. In addition, 

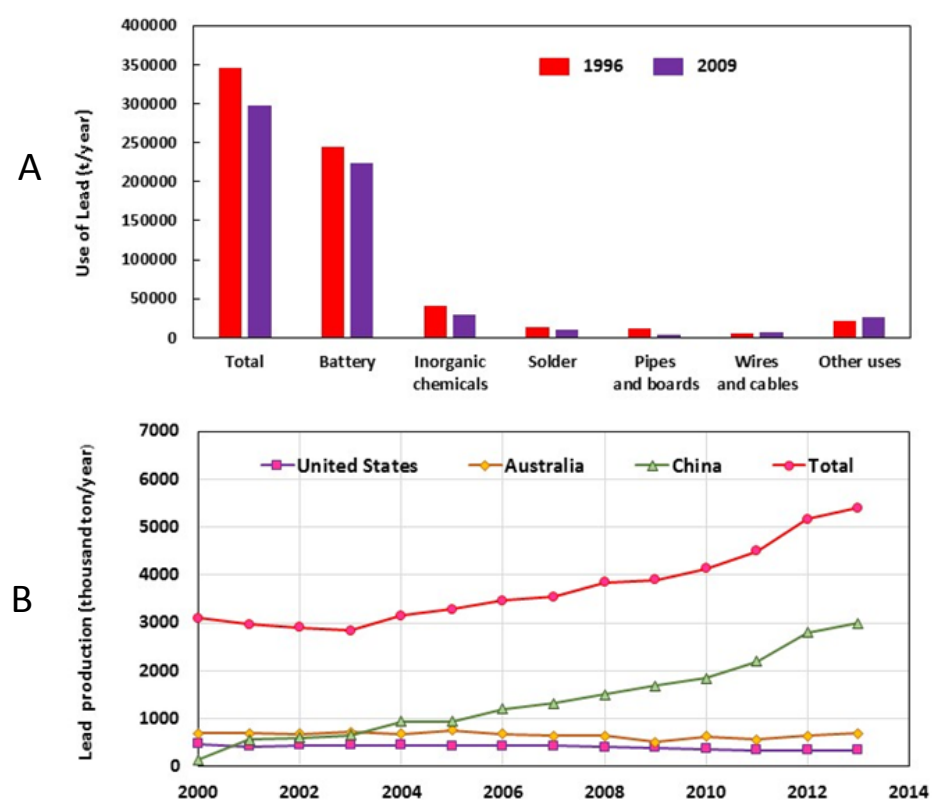

Figure 1. Lead use and lead production. A. The amount of lead used in various products in 1996 and 2009 in Japan. B. Worldwide lead production in leading countries.

it has been reported that lead may leak from WEEE and battery waste by the effect of acid rain. In 2000, the EU developed the "Directive of End-of-Life Vehicle (ELV)" to solve the problem of waste. The directive necessitated the recycling of end-of-life vehicles, and the ratio of lead recycling to collecting lead-acid batteries was improved. A similar recycling system has been constructed in Japan, and lead-acid battery recycling is additionally mandated by law.

The EU also issued a strict directive in 2003 on the restrictive use of certain hazardous substances in electrical and electronic equipment (referred to as the "Restriction of Hazardous Substances (RoHS) Directive"). The directive forbids the use of hazardous heavy metals (e.g., $\mathrm{Pb}, \mathrm{Hg}, \mathrm{Cd}$, and $\mathrm{Cr}(\mathrm{VI})$ ) in newly produced products of electrical and electric equipment. The United States also issued a similar law, the "Electric Waste Recycling Act of 2003." In compliance with these directives, lead-free products (solder, glass, and paint) have been developed, and the use of lead-free solder and lead-free paint is now the standard practice in Japan.

Another factor related to lead consumption is polyvinyl chloride consumption. In 2012, global polyvinyl chloride consumption was approximately 36 million tons. Polyvinyl chloride contains approximately 4, 500 ppm of lead stabilizer; thus, 162, 000 tons of lead stabilizer was exhausted as burned ash. The EU issued a strict directive on the management of packaging waste (Directive 94/62/EC), which banned the use of lead stabilizers in vinyl chloride production. To reach the target value of this directive, lead-free stabilizers, such as those containing $\mathrm{Ca}$ and $\mathrm{Zn}$, have been developed. Furthermore, old pipes and electrical codes made of polyvinyl chloride are gradually being changed to lead-free ones in homes and industries. 
A schematic illustration of lead recycling is shown in Figure 2. Recycled lead currently occupies $75 \%$ of the total lead produced by metallurgy in the EU, and this ratio is increasing. In Japan, over $90 \%$ of used lead in batteries was collected and reused in 2009 . If a $100 \%$ recycling ratio can be obtained and solder, polyvinyl chloride, paint, and glass can be converted to lead-free products as shown in Figure 2, lead emissions should theoretically become negligible.

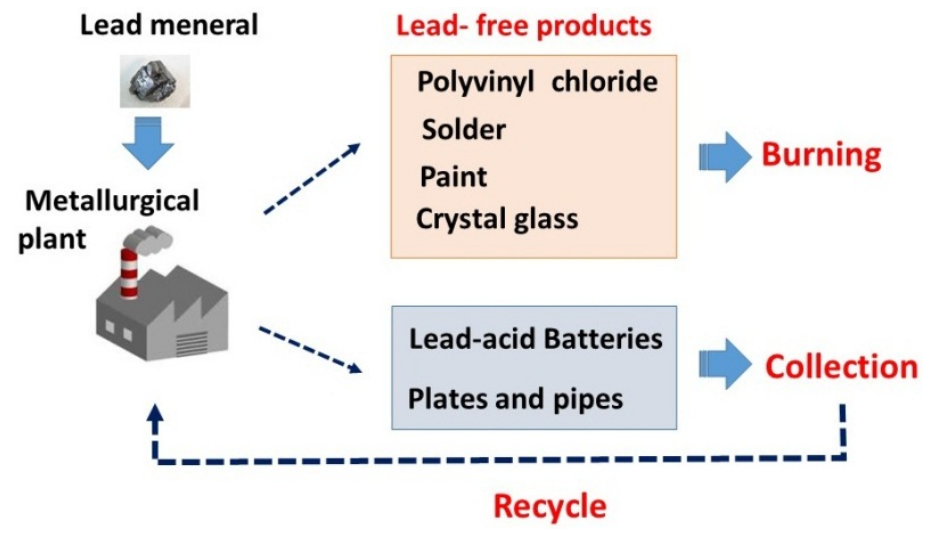

Figure 2. Schematic illustration of lead production and recycling.

\subsection{Causes of air and soil pollution from lead}

Due to the efforts to decrease lead emissions, air and soil pollution from lead has decreased. According to an investigation from the 1980s to 2000s on lead concentrations in the air and blood by Thomas et al. [11], the lead concentrations decreased after the ban on lead gasoline. Recently, the blood lead levels (BLLs) of inhabitants and the concentrations of lead in the air and soil in urban and agricultural areas have been investigated. The results suggest that the lead concentrations did not exceed nonpoisonous levels, even in the countries in which lead is produced $[12,13]$.

In the industrial areas where mining and metallurgy occurred, however, a significant amount of unusable lead was discarded in the soil, and effluent from the factories had been directly exhausted to the rivers without any posttreatment removal of heavy metals. In Uruguay, for example, drinking water and the soil are critically polluted by metallurgy industrial wastes because most of the hazardous wastes are dumped in the rivers [7]. Moreover, lead gasoline is still utilized in Uruguay, and many old cubes of tap water are made of lead. The BLLs in many Uruguayans are much higher than in other countries [14]. In mining areas (e.g., Paraná state) in Brazil, 177, 000 tons of waste from metallurgy and mining has remained in the soil for more than 60 years [15]. When lead concentrations in 171 soil portions were analyzed, extremely high concentrations $(10,000-52,000 \mathrm{mg} / \mathrm{kg})$ of lead were found in the soil near a metallurgy factory. Moreover, the inhabitants near a mining company in the Czech Republic had an average BLL of $37.2 \mu \mathrm{g} / \mathrm{dL}$, and $40 \%$ of the lead workers in the southwest of Nigeria 
had an average BLL of $60 \mu \mathrm{g} / \mathrm{dL}[16,17]$. Additionally, the soil near a car battery processing workshop in Kerman City, Iran, was found to contain 5, $780 \mathrm{mg} / \mathrm{kg}$ of lead [18]. The BLL of Indians near a residential area was $20-25 \mu \mathrm{g} / \mathrm{dL}$, and the lead concentration of PM10 (or PM2.5) in the residential area was very high $\left(10-14 \mathrm{mg} / \mathrm{m}^{3}\right)[11,19]$.

Soil pollution from lead was not observed in the major cities in China, such as Beijing and Hong Kong; therefore, the BLLs of inhabitants in these cities were normal (4-5 $\mu \mathrm{g} / \mathrm{dL})$ [20-22]. The number of mining and metallurgy factories is rapidly increasing in China due to the increased consumption of lead-acid batteries. However, no formal reports on the lead concentration and BLL have been reported in areas predominantly inhabited by mining and metallurgy factories, such as Zhejiang and Guangdong provinces. According to the WEB report [4], it is suspected that 100, 000 children are suffering due to lead toxicity. Therefore, in China, the areas predominantly inhabited by mining and/or metallurgy industries are thought to contain extremely high lead concentrations which are exhausted into the air, river, and soil.

Another potential cause of soil pollution from lead is a firing range. One of the worst cases of soil pollution from lead at a firing range demonstrated more than $10 \mathrm{~kg} / \mathrm{kg}$ of lead due to remnant lead alloy bullets. Therefore, lead pollution in firing ranges may be as harmful as in mining areas.

\subsection{Effects of lead pollution on the health of inhabitants living near metallurgy and mining areas}

The BLL is an indicator of pollution from lead. Lead decreases the IQ value when the BLL is greater than $20 \mu \mathrm{g} / \mathrm{dL}$ [23]. A test to measure the ability of recognition in monkeys suggested that dysgnosia was observed in monkeys with BLLs of 10-13 $\mu \mathrm{g} / \mathrm{dL}$. Moreover, lead toxicity was observed when the BLL exceeded $40 \mu \mathrm{g} / \mathrm{dL}$. According to recent studies, the BLL should be maintained below $10 \mu \mathrm{g} / \mathrm{dL}$ [24, 25].

The main route of exposure for an elevated BLL is ingestion. The amount of lead that adult subjects ingest from food is generally $20-25 \mu \mathrm{g} / \mathrm{kg}$ and $5-10 \%$ is absorbed. Approximately 100 $\mathrm{mg}$ of lead is present in the body. The sensitivity of lead in a child is much higher than in an adult because $40 \%$ of the ingested lead is absorbed. A previous report demonstrated that when more than $5 \mu \mathrm{g} / \mathrm{kg} /$ day of lead was ingested in infants, $32 \%$ of the lead was absorbed, although no accumulation was observed in infants who ingested less than $4 \mu \mathrm{g} / \mathrm{kg} / \mathrm{day}$. The WHO also suggested that the BLL was not increased in those who ingested less than $4 \mu \mathrm{g} / \mathrm{kg} /$ day [26].

The other most common route of exposure is polluted air. Approximately $40-50 \%$ of lead taken in from the nose is absorbed by the lung. The relationship between the concentration of lead in the air and the BLL is shown in Figure 3 (based on the data from the study by Thomas et al. on pollution from lead gasoline [11]). The BLL was found to be strongly correlated with air pollution.

Safety standards are defined to keep the environment safe. In Japan, the lead concentrations in the air and wastewater are below $1 \mathrm{ng} / \mathrm{m}^{3}$ and $0.01 \mathrm{mg} / \mathrm{L}$, respectively. Moreover, the normal BLL observed in Japanese is $1-3 \mu \mathrm{g} / \mathrm{dL}$, and the normal concentration of lead in the soil is 15$30 \mathrm{mg} / \mathrm{g}$. The lead concentrations in the areas near mining and metallurgy industries listed in 
Section 2.3 are greater than $1,000 \mathrm{mg} / \mathrm{kg}$, which are unusually high and dangerous. Therefore, to maintain a safe environment for those living near these areas, an effort to decrease lead emissions and remediation in these areas must be rapidly implemented.

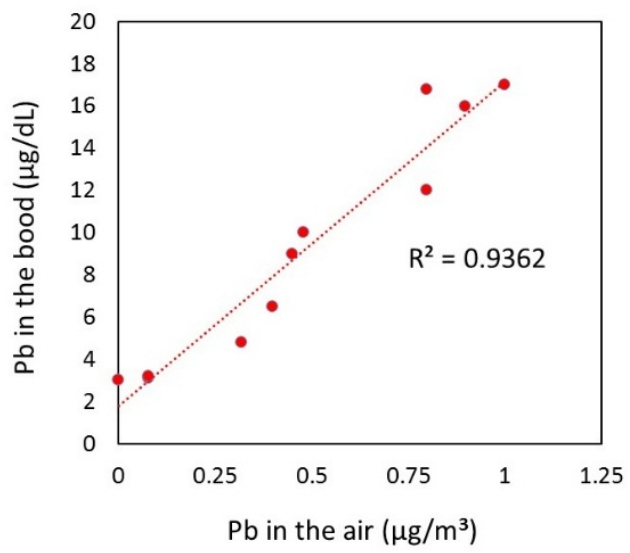

Figure 3. Effect of lead concentration in the air on the BLL. The figure was prepared based on the data from the study by Thomas et al. [11].

\section{Assessment of phytoextraction}

\subsection{Advantages of phytoextraction}

The remediation of polluted soil is extremely costly. In the United States, ten billion dollars were invested to remediate soil pollution in the 1990s. According to an approximate calculation of the cost [27], more than 100 billion dollars would be necessary for remediation of polluted soil in the 2000s; thus, an inexpensive process was sought to decrease the investment. Phytoextraction is a remarkable process where heavy metals can be absorbed from the soil and accumulated into plants at high concentrations without the use of expensive equipment. The advantages of phytoextraction also include increased safety and inexpensive running cost compared to physical and chemical methods, such as washing and solidification. Phytoremediation is an expanding market; in the United States and Japan, it is expected to result in 170 million dollars and 800 million yen, respectively.

The plants which contain the highest abilities of absorption are called "hyperaccumulators" and are the most suitable for the phytoextraction of heavy metals. With regard to lead, a hyperaccumulator is defined as a plant that is capable of accumulating greater than $1,000 \mathrm{mg} /$ $\mathrm{kg}$ dry biomass (or 100 times more than other plants) and generally shows a high tolerance to heavy metals. Some prominent hyperaccumulators have been screened and identified [28]. Stanleya pinnata, for example, was found to accumulate 3, $000 \mathrm{ppm}$ of selenium in its leaves 
when planted on soil containing 6 ppm of selenium [29]. Rinorea niccolifera was recently found in Western Luzon, Philippines, and could accumulate an unusually high amount (18, 000 ppm) of nickel by detoxifying with vacuoles [30]. R. niccolifera was the most prominent hyperaccumulator, because it was capable of absorbing heavy metals at a value several hundred times higher than other plants.

Additionally, an interesting tree was found in the Sabah Parks in Malaysia. The green sap of the tree contained high concentrations of nickel [31,32] and could be continuously collected. When the tree was planted in soil containing wastes from nearby mines, a green nickel-rich sap containing $20 \%$ nickel was collected from the trees. The ash of the burned sap additionally contained high concentrations of nickel (10-25\%), which corresponded to $200 \mathrm{~kg} / \mathrm{ha}(2,000$ dollars/ton). Those studies suggest that phytoextraction may be applicable to soil pollution from nickel.

\subsection{Phytoextraction of lead by a hyperaccumulator}

Hyperaccumulators absorbing lead have been screened as well as hyperaccumulators for other heavy metals. The chief hyperaccumulators introduced in this section are shown in Table 1. Thlaspi caerulescens [33], kenaf [34], sunflower [35], Cannabis sativa [36, 37], Tagetes minuta L. [38], cabbage [39], Brassica juncea [40], Acacia victoriae [41], and buckwheat are superior hyperaccumulators compared to other weeds and crops, and the following plants are especially remarkable. A. victoriae was found to be capable of accumulating $3,580 \mathrm{mg} / \mathrm{kg}$ of lead from a 1, $000 \mathrm{mg} / \mathrm{L}$ solution of lead nitrate. $B$. juncea additionally showed a high lead tolerance and could accumulate a significantly high concentration of lead $(34,500 \mathrm{mg} / \mathrm{kg})$. Furthermore, Shinshu buckwheat, an improved breed developed by Shinshu University, was capable of growing in soil containing more than $3,000 \mathrm{mg} / \mathrm{kg}$ of lead and could accumulate $6,000-10,000$ $\mathrm{mg} / \mathrm{kg}$ of lead. Buckwheat may be the most suitable plant because it is obtained at a high yield (700 g/ha/year) [42].

Additionally, two types of pteridophytes, Athyrium yokoscense and Pteris vittata, showed high tolerance to lead. A. yokoscense is typically found around mine areas containing high concentrations of heavy metals. It is known as an indicating plant to explore gold veins in Japan, as it lives in a cluster around areas of gold rubbish. One gametophyte of $A$. yokoscense was capable of accumulating high concentrations of lead $(10,000 \mathrm{mg} / \mathrm{kg})$ and showed tolerance to extremely high concentrations of lead [43]. P. vittata has been shown to accumulate arsenic. A breed belonging to $P$. vittata could accumulate $16,257.5 \mathrm{mg} / \mathrm{kg}$ of lead and grow in soil containing $92,900 \mathrm{mg} / \mathrm{kg}$ of lead. Additionally, it accumulated 4, $829 \mathrm{mg} / \mathrm{kg}$ of lead when it was grown in mine soil for six months [44].

The two types of mosses Scopelophila cataractae and Funaria hygrometrica were also identified as hyperaccumulators. S. cataractae, which is known as "copper moss" in Japan, was found in soil containing high concentrations of copper and could accumulate copper selectively at the cell wall. Moreover, a breed belonging to $S$. cataractae could accumulate lead as well as copper. F. hygrometrica additionally showed a very high ability of absorbing lead $[45,46]$. The reports by Riken (Japan) suggested that F. hygrometrica adsorbed $70 \%$ of lead per dry biomass when an effluent containing lead was supplied to the column containing the moss [47]. An advantage 
of using moss is that it can grow at a fast rate without water. Thus, mosses may be suitable for areas in which there is little water.

Ornamental plants adapted for phytoextraction were also screened. However, one such plant, Chlorophytum comosum, could only accumulate $516 \mathrm{mg} / \mathrm{kg}$ when 1, $250 \mathrm{mg} / \mathrm{kg}$ of lead was supplied in the soil [48]. The advantage of using ornamental plants is that the flowers may be reused after remediation [48, 49]. Moreover, ornamental plants do not show a high tolerance to lead. Therefore, they may be readily adapted for soil pollution in urban places because the lead concentrations in these areas are relatively low and the plants can be used in landscaping.

Trees have interesting characteristics for phytoextraction. The advantage of using a tree is that the root is much deeper, and therefore, it can be applied to the remediation of soil at a depth of 3-5 m. Conversely, the disadvantages are a slow growth rate and low tolerance to lead, although the biomass per land area is high. To overcome these disadvantages, the best trees were screened [50-52] and a combination of aspen and rowan trees [53], a combination of Ixora coccinea and Ficus benjamina [54], and the use of ornamental trees and timber trees [55] were examined to enhance the remediation efficiency. Additionally, a field trial experiment was performed [56,57] and the tree showing the highest ability for phytoextraction was Acacia mangium, which is widely used in an artificial forest in Malaysia because it is capable of growing well even in nutrient-poor soil and shows a high ability to adapt to its environment. It is known that the forest is the first stage in maintaining air and soil safety by capturing lead in the leaves [58]. The best candidate tree will be one that can effectively transfer lead to its leaves or sap, because leaves and sap can be easily and continuously collected.

\begin{tabular}{lll}
\hline Plants & Species & $\begin{array}{l}\mathbf{P b} \\
\mathbf{( m g} / \mathbf{k g})\end{array}$ \\
\hline Weeds & Brassica juncea & 34,500 \\
\hline Shinshu buckwheat & 22,363 \\
\hline Cabbage & Athyrium yokoscense & 5,010 \\
\hline Pteridophytes & Pteris vittata & 16257.5 \\
\hline Moss & Funaria hygrometrica & 16257.5 \\
\hline Flower & Chlorophytum comosum & $1,000-26,000$ \\
\hline Tree & Acacia mangium & 516 \\
\hline
\end{tabular}

Table 1. Amounts of lead absorbed by important hyperaccumulators

\subsection{Enhancement of the efficiency of phytoextraction using ethylenediaminetetraacetic acid (EDTA)}

Lead readily converts to lead(II) oxide $(\mathrm{PbO})$ through contact with oxygen in the air. The resultant $\mathrm{PbO}$ slowly converts to inorganic salts of lead, such as $\mathrm{Pb}\left(\mathrm{NO}_{3}\right)_{2}, \mathrm{PbSO}_{4}$, and $\mathrm{PbCO}_{3}$, 
by acid rain containing nitrate and sulfate ions or water saturating carbon dioxide (containing carbonate ions). Table 2 shows the solubility of inorganic salts of lead [59]. The solubility of $\mathrm{PbSO}_{4}$ and $\mathrm{PbCO}_{3}$ is very low. Inorganic salts and free lead ions are adsorbed on particles in the soil by forming a complex with organic compounds contained in the particles [60,61] and gradually changed to more insoluble compounds by reacting with phosphate. Therefore, the concentration of free lead ions in the soil is extremely low. The rapid absorption by plants is disturbed due to the low concentration of free lead ions or its inorganic salts. The amount of free lead ions must be increased by removing lead salts adsorbed in the soil particles for rapid absorption.

Many methods to increase the efficiency of phytoextraction have been reported [62], and the best method was to supply ethylenediaminetetraacetic acid (EDTA) to the soil. The complex formation constants (pK) of EDTA to $\mathrm{Pb}(\mathrm{II}), \mathrm{Cd}(\mathrm{II}), \mathrm{Zn}(\mathrm{II})$, and $\mathrm{Fe}(\mathrm{III})$ are 18.3, 16.6, 16.7, and 24.2, respectively. Therefore, the lead ions of inorganic salts (or $\mathrm{PbO}$ ) in the soil positively conform the complex followed by the addition of EDTA $(\mathrm{pH}<7)$ [63]. In a pilot experiment, when the soil containing $1,935 \mathrm{mg} / \mathrm{kg}$ of lead was washed with water containing EDTA, $97 \%$ of lead was extracted from the soil [64,65].

\begin{tabular}{cc}
\hline Compound & $\begin{array}{l}\text { Solubility to water } \\
\text { g/100 } \mathbf{H}_{\mathbf{2}} \mathbf{O}\left(\mathbf{2 0}{ }^{\circ} \mathrm{C}\right)\end{array}$ \\
\hline $\mathrm{Pb}$ & $3.1 \times 10^{-5}$ \\
\hline $\mathrm{PbO}$ & $5.04 \times 10^{-3}(\alpha$ form $)$ \\
\hline $\mathrm{Pb}_{3}\left(\mathrm{PO}_{4}\right)_{2}$ & $1.4 \times 10^{-5}$ \\
\hline $\mathrm{PbHPO}_{4}$ & $2.187 \times 10^{-2}$ \\
\hline $\mathrm{Pb}\left(\mathrm{NO}_{3}\right)_{2}$ & 54.3 \\
\hline $\mathrm{PbCO}_{3}$ & $7.269 \times 10^{-5}$ \\
\hline $\mathrm{PbS}$ & $6.77 \times 10^{-13}$ \\
\hline $\mathrm{PbSO}_{4}$ & $3.836 \times 10^{-3}$ \\
\hline $\mathrm{Pb}(\mathrm{OH})_{2}$ & $1.615 \times 10^{-3}$ \\
\hline $\mathrm{Pb}\left(\mathrm{CH}{ }_{3} \mathrm{COO}\right)_{2}$ & 44.3 \\
\hline &
\end{tabular}

Table 2. Solubility of lead and its inorganic salts in water. This table is based on the WEB data [59]

Moreover, the processing time and accumulation in phytoextraction can be drastically shortened and enhanced by EDTA. For example, Scirpus Maritimus L. could adsorb 80 \% of lead in the root within 60 days when $5 \mathrm{mmol} / \mathrm{kg}$ EDTA was supplied [66]. Absorbed amounts of lead in Zea mays L. and Pisum sativum L. were enhanced to 120 times [67], and Indian mustard Brassica juncea had increased absorption when EDTA was supplied [68]. Kos et al. [38] investigated the effect of $5 \mathrm{mmol} / \mathrm{kg}$ EDTA or $10 \mathrm{mmol} / \mathrm{kg}$ ethylenediamine- $\mathrm{N}$, N'-disuccinic acid (EDDS) on lead accumulation in various plants, and the results suggest that Cannabis sativa contained the best phytoremediation potential (26.3 kg/ha) and accumulated 1, $053 \mathrm{mg} /$ 
$\mathrm{kg}$ of lead. Furthermore, for cabbage (a high-biomass crop), the accumulation and treatment period was enhanced $(5,010 \mathrm{mg} / \mathrm{kg}$ ) and shortened, respectively, when $3.0 \mathrm{mmol} / \mathrm{kg}$ EDTA was supplied for seven days [40]. When buckwheat was cultivated in soil containing 13, 032 $\mathrm{mg} / \mathrm{kg}$ of lead and EDTA and citric acid were supplied for two months, 22, $363 \mathrm{mg} / \mathrm{kg}$ of lead was accumulated in the shoots and leaves [69]. These results suggest that EDTA is effective for increasing the absorption of lead in plants.

However, there are several disadvantages for the use of EDTA. One is the low degrading characteristic of EDTA [70]. EDTA supplied in the soil exists without degradation for a long period of time and slowly degrades to diketopiperazines, which are toxic compounds. To solve this problem, EDDS, which has a higher biodegradability than EDTA, has been used [71-73], although the complex formation constants (pK) of EDDS are lower than that of EDTA and an unfavorable exchange between lead and the others often occurred [67, 68]. Another disadvantage is the elution of other metal ions following the use of EDTA. The addition of EDTA in the soil causes the leakage of important minerals (e.g., $\mathrm{Mg}$ and $\mathrm{Ca}$ ) necessary for the plant growth, and the effluent containing toxic ions (e.g., $\mathrm{Pb}, \mathrm{Hg}$, and $\mathrm{As}$ ) pollutes the groundwater [74]. Therefore, EDTA or EDDS must be applied to the soil at the lowest effective concentrations.

\subsection{Improved procedure for the phytoextraction of lead}

Two devises have been proposed to enhance the concentration of free lead ions or its inorganic salts. One is an electro-phytoextraction process. Electro-phytoextraction is performed under an electric field and can enhance the performance. For example, the absorption in ryegrass was enhanced when $1.0 \mathrm{~V} / \mathrm{cm}$ of DC electrical field was given to the soil in a vertical direction [75], and the absorption in Brassica juncea was enhanced when an electric field was given at four times over $30 \mathrm{~V}$ [76]. Additionally, when $1.0 \mathrm{~V} / \mathrm{cm}$ of AC electrical field, as well as DC, was given to rapeseed (Brassica napus) and tobacco (Nicotiana tabacum), the absorption of Cd and $\mathrm{Pb}$ in the shoots was enhanced [77].

Another device used to improve phytoextraction is the use of acid [78, 79]. The concentration of free lead is increased when the $\mathrm{pH}$ of the soil is more acidic (near $\mathrm{pH}$ 5). The solubility of lead phosphate, which is an insoluble compound, was enhanced by a $0.15 \mathrm{M}$ citric acid solution [80], and oxalic acid was the best at enhancing the solubility of pyromorphite $\left(\mathrm{Pb}_{5}\left(\mathrm{PO}_{4}\right)_{3} \mathrm{Cl}\right)$, an insoluble phosphate [81, 82]. Because microorganisms can secrete various acids, such as acetic, citric, and lactic acids, the soil $\mathrm{pH}$ may be decreased by supplements of these microorganisms. The effects of urea [83] and other chelate compounds [84, 85], as well as the effect of acids, were examined. The cells of Rhizobacteria could enhance the concentration of free lead by secreting siderophores [86] and aided in plant growth by secreting indoleacetic acid (IAA), a plant growth factor. Such microorganisms are referred to as "plant-growth-promoting rhizobacteria" (PERG) [87, 88].

\subsection{Transgenic approach to improve the phytoextraction of lead}

The improvement of a hyperaccumulator via gene manipulation is the most effective way to enhance its ability. Transgenic plants have been energetically developed since the 1990s 
[89-92]. Transgenic plants which could increase the volatility of heavy metals or decrease the toxicity of heavy metals may be the best candidates because the remediation process can be continuously carried out without removing the plants. Transgenic B. juncea, for example, expressing the cystathionine gamma-synthase gene of Arabidopsis thaliana L. could convert selenium to volatile dimethylselenium [93, 94], and a plant expressing the methylmercury lyase gene decreased the toxicity by reducing methylmercury to mercury [95]. However, vaporization is not acceptable for lead because methylated lead diffuses into the air and exhibits a high toxicity as previously described.

Thus, the following two mechanisms have been proposed. One method is to enhance the number of compounds capable of combining heavy metals, such as metallothionein, glutathione, and phytochelatin. For example, the absorption efficiency of transgenic B. juncea expressing adenosine triphosphate sulfurylase, glutamyl-cysteine synthetase, and glutathione synthetase genes was 4.3 times higher than that in the wild plant [96]. Moreover, the accumulation in Nicotiana glauca expressing phytochelatin synthase was also enhanced [97]. The other mechanism is to obtain a high lead tolerance by enhancing the transport into the cell and vascular membranes. Higher tolerance and accumulation of $\mathrm{Zn}, \mathrm{Mn}$, and $\mathrm{Cd}$ were realized by the plants transformed with a zinc transporter (ZAT or AtMTP1), ShMTP, CAX2, AtMHX [89-91] or the AtNramp, AtPDR8, and AtATM3 genes of ABC transporters [98, 99]. For lead accumulation, the following transgenic plants were studied: tobacco plants expressing the calmodulin-binding protein gene of Nicotiana tabacum (NtCBP4) [100] and Arabidopsis plants expressing the ZntA [101], which codes for the zinc transporter in E. coli, and an enhanced accumulation of lead, as well as other heavy metals, was observed. The yeast $Y C F 1$ gene codes for a transporter of vacuolar storage of $\mathrm{Cd} / \mathrm{Pb}$. A thaliana expressing the $Y C F 1$ gene showed a high resistance to $\mathrm{Cd}$ and $\mathrm{Pb}$ and accumulated those heavy metals [102]. Transgenic poplar trees expressing the $Y C F 1$ gene also developed a high resistance to $\mathrm{Cd}$ and $\mathrm{Pb}$ [103]. Moreover, a study conducted by Mizuno et al. showed that transgenic $A$. thaliana had longer roots (2.5 times longer) and a higher (3-14 times higher) accumulation of lead when the FeMRP3 gene of buckwheat was expressed in A. thaliana.

\subsection{Assessment of efficiency of phytoextraction}

The author assessed the efficiency of phytoextraction in contaminated soil by lead. The most advantageous point of phytoremediation is its profitability. By the author's rough estimate, the income generated by the phytoremediation process is approximately 340, 000 dollars/ha for cases where it is assumed that (1) pollution is present at $1 \mathrm{~m}$ in depth and $10 \mathrm{~g} / \mathrm{kg}$ of lead is contained in the soil (density: 1.7), (2) $100 \%$ of the lead is extracted from the soil, and (3) the price of lead is 2, 000 dollars/ton. However, the approximation of the necessary expenses is much higher according to some reports and are estimated to be as high as 300, 000-5, 000, 000 dollars/ha (lowest estimation: 2, 500-15, 000) [104]. The difference in the costs suggests that further efforts are necessary to decrease the expenses in order to improve the application of phytoextraction.

The high necessary expenses of phytoextraction are due to the low yield per treatment period and the time-consuming posttreatment heavy metal recycling from the biomass. Even in 
buckwheat, which is one of the best hyperaccumulators for lead, the amount of lead absorption is only $20 \mathrm{~kg} /$ year (dual cropping), when the yield and adsorption ability are assumed to be 1 $\mathrm{t} / \mathrm{ha}$ and $10 \mathrm{~g} / \mathrm{kg}$. Moreover, the plant absorbing lead must be dried, burned, and extracted to recycle the lead. The cost for those operations accounts for half of the total cost. Consequently, a hyperaccumulator with a fast growth time and a fast absorption rate, as well as a high accumulation ability, is required to overcome the problem of high necessary expenses.

Furthermore, the effect on the environment should be considered. Indigenous species do not necessarily have a superior ability for phytoremediation, although the use of indigenous species is acceptable [105]. The planting of a nonnative hyperaccumulator often changes the natural flora or may destroy the indigenous species because hyperaccumulators have an increased ability to adapt to the environment. This is particularly true for transgenic plants. Therefore, special consideration for the environment and a general consensus in the society are necessary.

In conclusion, further efforts to decrease the necessary expenses must be undertaken for the widespread use of phytoextraction, although phytoextraction is a remarkable procedure for recycling lead in the soil. For example, some weeds are capable of easily and rapidly reproducing even when most of the shoots and leaves are removed. The advantages of using a weed for phytoextraction include the following: (1) lead can be continuously obtained from the leaves and shoots, (2) the growth and absorption can be completed in a short period of time, and (3) the posttreatment is inexpensive. Therefore, the author suggests that the ideal phytoextraction process includes the use of such a weed.

\section{Assessment of the remediation of lead by microorganisms}

\subsection{Microorganisms adapted for lead absorption}

Some microorganisms contain a high ability to adsorb and absorb lead [106-108], and the mechanism through which microorganisms achieve this can be classified into four mechanisms (Table 3). The first mechanism is the absorption of lead by secreting extracellular polymers. The typical extracellular polymer is polysaccharide, which rapidly combines lead at a high affinity. Halomonus sp. [109], Staurastrum sp. [110], Bacillus firmus [111], Paenibacillus jamilae [112], and Pseudomonas sp. are known as microorganisms that secrete polysaccharides. The polysaccharide secreted by $B$. firmus cells, for example, was capable of adsorbing $98.3 \%$ of $\mathrm{Pb}$ at an optimum $\mathrm{pH}$, and $2 \mathrm{~g} / \mathrm{L}$ of polysaccharide produced by $P$. jamilae, an endospore-forming bacillus, specifically adsorbed $230 \mathrm{mg} / \mathrm{g}$ of lead.

The second mechanism is adsorption at the cell wall. Bacillus sp. [113], Pseudomonas aeruginosa [114], Synechococcus sp. [115], Saccharomyces cerevisiae [116], and fungi (such as Aspergillus flavus [117] and Corollospora lacera [118]) were highly efficient in the adsorption of lead; the amounts of lead absorbed by P. aeruginosa, S. cerevisiae, and C. lacera were 123, 250, and 270.3 $\mathrm{mg} / \mathrm{g}$ dry biomass, respectively. 
The third mechanism is the binding of lead inside the cell through phytochelatins, metallothioneins, and siderophores. Phytochelatins are produced by some microorganisms, such as Schizosaccharomyces sp. Metallothioneins produced by Bacillus [119], Streptomyces sp. [120], and $P$. aeruginosa [121] are capable of combining with $\mathrm{Pb}(\mathrm{II})$, although metallothioneins typically combine with copper or zinc ions. Moreover, the yellow-green fluorescent pyoverdine and pyochelin produced by Pseudomonas putida KNP9 [122] and P. aeruginosa PAO1 [123] were capable of combining with $\mathrm{Pb}(\mathrm{II})$.

The fourth mechanism is the precipitation of lead inside the cell. For example, Staphylococcus aureus [124], Vibrio harveyi [125], and Enterobacter cloacae [126] are capable of producing $\mathrm{Pb}_{3}\left(\mathrm{PO}_{4}\right)_{2}, \mathrm{~Pb}_{6}\left(\mathrm{PO}_{4}\right)_{6}$, and $\mathrm{Pb}\left(\mathrm{PO}_{4}\right)_{3} \mathrm{Cl}$, respectively, by binding with phosphate, and sulfurreducing bacteria produce $\mathrm{PbS}$ [127].

Furthermore, using genetic techniques, these abilities could be enhanced. For example, the amount of $\mathrm{Cd}$ accumulation was seven times higher when the phytochelatin synthesis gene of Schizosaccharomyces pombe was expressed in P. putida KT2440. The genes associated with metallothioneins, siderophores, and phytochelatins were precisely examined [128-131], and recombinants expressing these genes at a high level may be useful for enhancing the accumulation of lead.

\subsection{Novel bioremediation process of heavy metals using microorganisms}

As introduced in Section 4.1, some microorganisms showed a high ability for lead accumulation (> $300 \mathrm{mg} / \mathrm{g}$ ), which was higher than the plant hyperaccumulators. However, few microorganisms have been utilized for the bioremediation of soil polluted by lead. The reason is that the collection of such microorganisms from soil followed by adsorption is extremely difficult. If the microorganisms can be readily collected from the soil, then bioremediation with microorganisms becomes an effective process. Thus, the author developed a novel bioremediation method which combines the immobilized technique with landfarming, referred to as the landfarming with immobilized microorganisms (LIM) method.

The LIM method consists of four steps, shown in Figure 4. In the first step, the beads (approximately $0.35-0.4 \mathrm{~cm}$ in diameter) immobilized with microbial cells which demonstrate a high ability of absorption to lead are prepared and mixed with contaminated soil while plowing the field by the landfarming process. The soil is oxygenated by the operation, and the immobilized microbial cells contained in the beads are activated by the increased oxygen supply. In the second step, the plowed soil containing the cell beads is incubated for a defined period. The lead is absorbed (or adsorbed) by the microbial cells during this period. In the third step, the soil containing the beads is collected, and the beads are separated from the soil with sieves of adequate mesh sizes $(0.25$ and $0.50 \mathrm{~cm})$. Thus, the beads can be easily collected. In the fourth step, lead absorbed (or adsorbed) in the cells is extracted with a small amount of nitric acid. The separated soil by the sieves is recycled by returning it to its point of origin, and the beads flowed by extraction are reused in the next remediation. 


\begin{tabular}{|c|c|c|}
\hline Mechanism & Compound for absorption & Typical species \\
\hline Absorption by & Polysaccharides & Halomonus sp. \\
\hline extracellular & & Staurastrum sp. \\
\hline \multirow[t]{2}{*}{ polymer } & & Bacillus firmus \\
\hline & & Paenibacillus jamilae \\
\hline \multirow[t]{6}{*}{ Absorption by cell wall } & Peptidoglycan & Pseudomonas aeruginosa \\
\hline & & Bacillus sp. \\
\hline & & Synechococcus sp. \\
\hline & & Saccharomyces cerevisiae \\
\hline & & Aspergillus flavus \\
\hline & & Corollospora lacera \\
\hline \multirow[t]{6}{*}{ Binding within cells } & Phytochelatin & Schizosaccharomyces sp. \\
\hline & Metallothionein & Bacillus sp. \\
\hline & & Streptomyces sp \\
\hline & & Pseudomonas aeruginosa \\
\hline & Pyoverdine & Pseudomonas putida \\
\hline & Pyochelin & Pseudomonas aeruginosa \\
\hline \multirow[t]{4}{*}{ Precipitation within cells } & $\mathrm{Pb}_{3}\left(\mathrm{PO}_{4}\right)_{2}$ & Staphylococcus aureus \\
\hline & $\mathrm{Pb}_{6}\left(\mathrm{PO}_{4}\right)_{6}$ & Vibrio harveyi \\
\hline & $\mathrm{Pb}\left(\mathrm{PO}_{4}\right)_{3} \mathrm{Cl}$ & Enterobactor cloacae \\
\hline & $\mathrm{PbS}$ & Sulfur-reducing bacteria \\
\hline
\end{tabular}

Table 3. Various mechanisms to adsorb or absorb lead by microorganisms

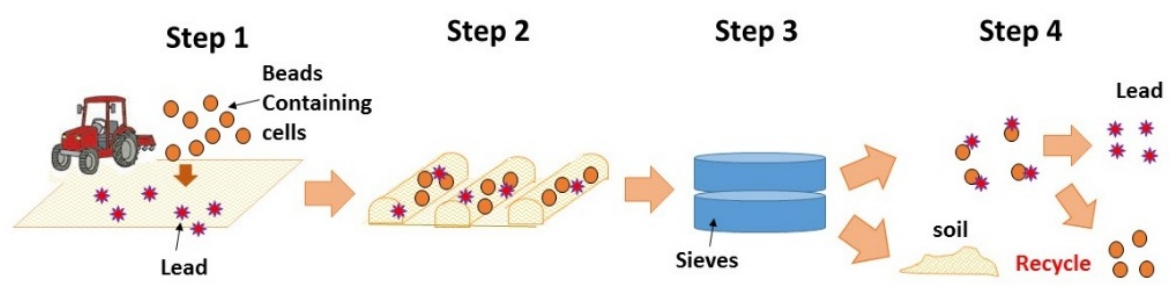

Step 1: The field is plowed and the soil is mixed with beads of the immobilized cells. Step 2: The plowed field is incubated for a defined period to absorb lead. Step 3: The beads are separated using sieves. Step 4: Lead is extracted from the beads, and the resultant beads and sifted soil are recycled.

Figure 4. The LIM method. 


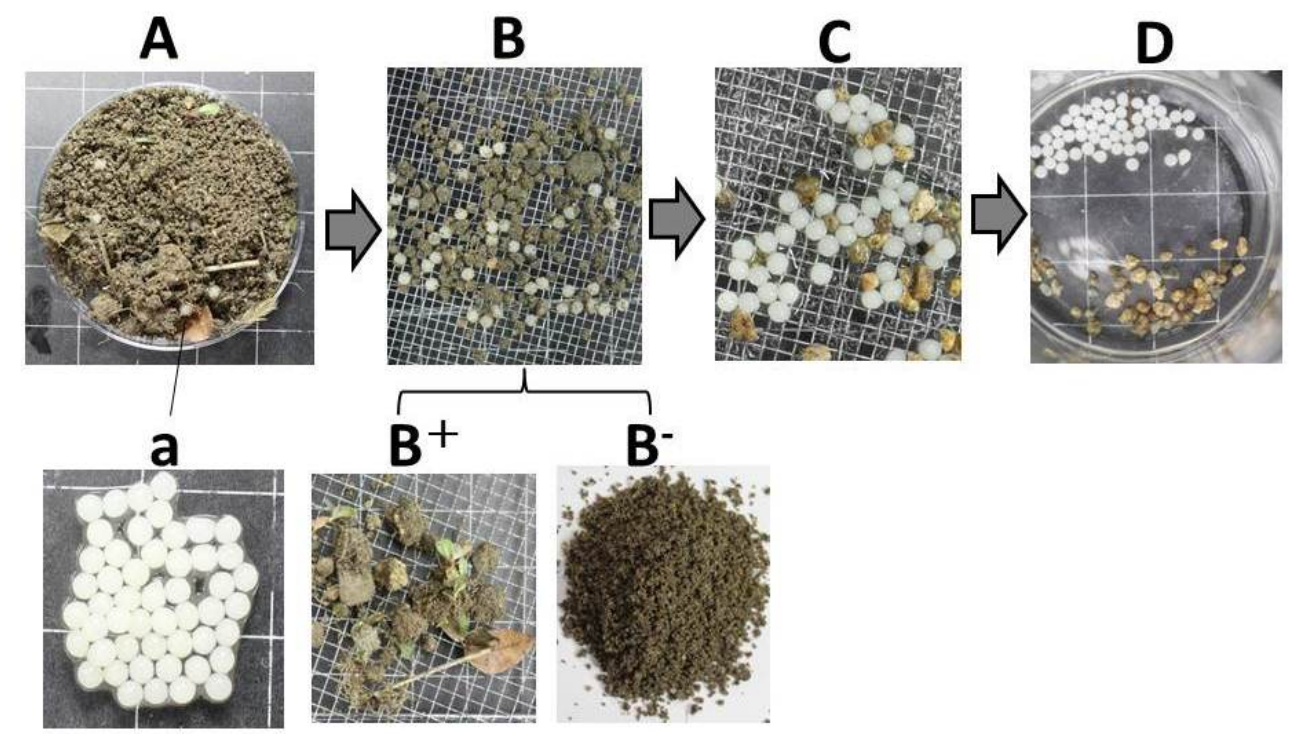

$\overline{\text { A. Soil containing }}$ the beads. Fifty beads were mixed with $50 \mathrm{~g}$ of soil (Hyoko, Japan). a. Beads made of alginate gel $(0.38 \mathrm{~mm}$ in diameter). B. The soil and beads were separated by sieves with mesh sizes between $2.5 \mathrm{~mm}$ and $5 \mathrm{~mm}$. B+ and B-. The impassable soil through the $5 \mathrm{~mm}$ mesh sieve and the passed soil through the $2.5 \mathrm{~mm}$ mesh sieve are shown. C. The washed soil and beads in water. D. Extraction of lead from the beads by nitric acid.

Figure 5. Schematic illustration of the LIM method using alginate gel beads.

The beads made of alginate gel are most suitable for the LIM method because (1) they can be easily and inexpensively produced at a uniform size, (2) they can immobilize microbial cells at a high density (approximately 100-1,000 $\mathrm{mg}$ dry cells $/ \mathrm{cm}^{3}$ ), and (3) they have an appropriate hardness. If it is assumed that the immobilized cell can accumulate lead at $300 \mathrm{mg} / \mathrm{g}$, one bead should be able to absorb 3-30 mg of lead. Additionally, if cells secreting polysaccharides are utilized, each bead may be applied several times for remediation because polysaccharides are not leaked from the beads. Therefore, alginate gel beads can be utilized as a superior absorbent of lead.

Figure 5 shows the separation experiment of the beads and soil from the soil and beads mixture (Fig. 4, Step 3). The experiment was performed to examine the separation efficiency of the beads; the absorption by the immobilized cells was not conducted. Fifty beads $(0.38 \mathrm{~mm}$ in diameter) were mixed with $50 \mathrm{~g}$ of soil (Fig. 5A) and separated with $2.5 \mathrm{~mm}$ and $5 \mathrm{~mm}$ mesh sieves. All beads were collected between $2.5 \mathrm{~mm}$ and $5 \mathrm{~mm}$ mesh sieves (Fig. 5B) and the soil was eliminated from the $2.5 \mathrm{~mm}$ mesh sieve by rinsing with water (Fig. 5C). Heavy metals were extracted by a small amount of nitric acid (Fig. 5D). Following extraction, the beads may be reused in the next remediation because the beads are not broken by the operation and can be easily separated with small stones (Fig. 5D). 
The advantage of the LIM method is that the processing time is short and the beads may be readily collected and reused for the extraction operation. Therefore, the LIM method has a high potential for remediating the soil contaminated by lead. This method may become an important process for remediation of soil in the future, although the proper procedure and efficiency of the LIM method must be further investigated.

\section{Conclusion}

A review of the estimated causes of pollution from lead and the following results were discussed. The principal use of lead is due to the production of lead-acid batteries; other uses include inorganic chemicals, solder, tubes, and boards. Following the RoHS Directive, the recycling percentage of lead-acid batteries and crystal glass has gradually increased, and solder, paint, and vinyl chloride containing lead have been converted to lead-free products. Over $80 \%$ of lead is currently recycled in the developed countries. Therefore, serious pollution from lead is low in urban and agricultural areas. However, life-threatening levels of pollution from lead exist in areas containing metallurgy and mining industries in Asia, Africa, and South America due to the dumping of wastes in the rivers and in the air without any posttreatments. The soil in these areas should be promptly remediated.

Next, the author estimated whether phytoextraction is a practical method for remediation. Many native or transgenic plants showing a high accumulation ability to lead were screened or developed, and the ability could be enhanced using EDTA and microorganisms. Therefore, phytoextraction is a promising method for remediation. However, further improvement of the method is necessary due to the long processing time and low capacity (biomass/planted area).

Finally, the author proposed a novel process for remediation using microorganisms. Few microorganisms have been used for the bioremediation of polluted soil by heavy metals because it is often exceedingly difficult to collect the microorganisms from the soil after absorption. The LIM method, which is proposed by the author, is the improved landfarming process which employs beads with immobilized cells. In the LIM method, the processing time is short and the beads may be easily collected from soil with sieves after absorption. Therefore, the LIM method has high potential and may become the ideal process for the remediation of soil contaminated by lead.

\section{Acknowledgements}

The author sincerely thanks Professor Kenichiro Suetugu at Kobe University for his helpful suggestions and Ms. Keiko Watanabe for her great technical assistance to this study. The research was supported by a grant-in-aid from the School of Human Sciences at Kobe College. 


\section{Author details}

Naofumi Shiomi

Address all correspondence to: n-shiomi@mail.kobe-c.ac.jp

Department of Human Sciences, Kobe College, Hyogo, Japan

\section{References}

[1] Mukherjee A., Sengupta M.K., Hossain M.A., Ahamed S., Das B., Nayak B., Lodh D., Rahman M.M., Chakraborti D. Arsenic Contamination in Groundwater: A Global Perspective with Emphasis on the Asian Scenario. Journal of Health, Population, and Nutrition 2006; 24(2): 142-163.

[2] Zhang L., Chen C. Geographic Distribution and Exposure Population of Drinking Water with High Concentration of Arsenic in China. Journal of Hygiene Research 1997; 26(5): 310-313.

[3] Berny P.J., Côté L.M., Buck W.B. Relationship Between Soil Lead, Dust Lead, and Blood Lead Concentrations in Pets and Their Owners: Evaluation of Soil Lead Threshold Values. Environmental Research 1994; 67(1): 84-97.

[4] Cun Z. Chinese Children Suffer Failure to Tackle Lead Poisoning. China Dialogue. https://www.chinadialogue.net/article/show/single/en/5974-Chinese-children-sufferfailure-to-tackle-lead-poisoning

[5] Lah K. History of Lead Use. Toxipedia.

[6] Lead Gasoline-International Pattern of Use. Groval Oppotunities for Reducing the Use of Leaded Gasoline. http://www.chem.unep.ch/pops/pdf/lead/leadgas

[7] Rebfrew D. In the Margins of Contamination: Lead Poisoning and the Production of Neoliberal Nature in Uruguay. Journal of Political Ecology 2009; 16: 87-103.

[8] Report of Ministry of the Environment. Goverment of Japan. http://www.env.go.jp/ recycle/report/h17-02/full.pdf

[9] Mineral Commodity Summaries in USSG. http://minerals.usgs.gov/ minerals/pubs/ commodity/barite/

[10] Waste Electrical \& Electronic Equipment (WEEE). European Commission. http:// ec.europa.eu/environment/waste/weee/index_en.htm

[11] Thomas V.T., Socolow R.H., Fanelli J.J., Spiro T.G. Effects of Reducing Lead in Gasoline: An Analysis of the International Experience. Environmental Science \& Technology 1999; 33(22): 3942-3948. 
[12] Patel K.S., Ambade B., Sharma S, Sahu D., Jaiswal N.K., Gupta S., Dewangan R.K., Nava S., Lucarelli F., Blazhev B., Stefanova R, Lucarelli J. Lead Enviromental Pollution in Central India. In: Ramau B. (ed) New Trends in Technologies, Rijeka: InTech; 2010.

[13] Waseem A., Arshad J., Iqbal F., Sajjad A., Mehmood Z., Murtaza G. Pollution Status of Pakistan: A Retrospective Review on Heavy Metal Contamination of Water, Soil, and Vegetables. BioMed Research International 2014; Article ID 813206, 29 pages. http://dx.doi.org/10.1155/2014/813206

[14] Cousillas A., Pereira L., Alvarez C., Heller T., De Mattos B., Piastra C., Viapiana P., Rampoldi O., Mañay N. Comparative Study of Blood Lead Levels in Uruguayan Children (1994-2004). Biological Trace Element Research 2008; 122(1): 19-25.

[15] Piedade T.C., Melo V.F., Souza L.C., Dieckow J. Three-Dimensional Data Interpolation for Environmental Purpose: Lead in Contaminated Soils in Southern Brazil. Environmental Monitoring and Assessment 2014; 186(9): 5625-5638.

[16] Cikrt M., Smerhovsky Z., Blaha K, Nerudova J., Sediva V., Fornuskova H., Knotkova J., Roth Z., Kodl M., Fitzgerald E., Biological Monitoring of Child Lead Exposure in the Czech Republic. Environmental Health Perspective 1997; 105(4): 406-411.

[17] Adeniyi F.A., Anetor J.I. Lead-Poisoning in Two Distant States of Nigeria: An Indication of the Real Size of the Problem. African Journal of Medicine and Medical Sciences 1999; 28(1-2): 107-112.

[18] Hamzeh M.A., Aftabi A., Mirzaee M. Assessing Geochemical Influence of Traffic and Other Vehicle-Related Activities on Heavy Metal Contamination in Urban Soils of Kerman City, Using a GIS-Based Approach. Environmental Geochemistry and Health 2011; 33(6): 577-594.

[19] Ahamed M., Verma S., Kumar A., Siddiqui M.K. Blood Lead Levels in Children of Lucknow, India. Environmental Toxicology 2010; 25(1): 48-54.

[20] Li M.M., Cao J., Xu J., Cai S.Z, Shen X.M., Yan C.H. The National Trend of Blood Lead Levels Among Chinese Children Aged 0-18 Years Old, 1990-2012. Environmental International 2014; 71: 109-117.

[21] Mao Q., Huang G., Ma K., Sun Z. Variation of Soil Lead in Different Lead Uses Along the Urbanization Gradient in the Beijing Metropolitan Area. International Journal of Environmental Research and Public Health 2014; 11(3): 3199-3214.

[22] Li T., Dai Y.H., Xie X.H., Tan Z.W., Zhang S.M., Zhu Z.H. Surveillance of Childhood Blood Lead Levels in 11 Cities of China. World Journal of Pediatrics 2014; 10(1): 29-37.

[23] Schwartz J. Low-Level Exprosure and Children's IQ: A Meta-Analysis and Search for a Threshold. Environmental Research 1994; 64: 42-55. 
[24] Carrington C.D., Sheehan D.M., Bolger P.M. Hazard Assessment of Lead. Food Additives and Contaminants 1993; 10(3): 325-335.

[25] Binns H.J., Campbell C., Brown M.J. Interpreting and Managing Blood Lead Levels of Less than $10 \mathrm{Microg} / \mathrm{dL}$ in Children and Reducing Childhood Exposure to Lead: Recommendations of the Centers for Disease Control and Prevention Advisory Committee on Childhood Lead Poisoning Prevention. Pediatrics 2007; 120(5): e1285-e1298.

[26] Ziegler E.E., Edwards B.B., Jensen R.L., Mahaffey K.R., Fomon S.J. Absorption and Retention of Lead by Infants. Pediatric Research 1978; 12(1): 29-34.

[27] Cookson J.R. Phytoremediation Engineering: Design and Application. NewYork: McGraw-Hill Inc.; 1995.

[28] Polland A.J., Reeves R.D., Baker A.J.M. Facultative Hyperaccumulation of Heavy Metals and Metalloids. Plant Science 2014; 217-218: 8-17.

[29] Freeman J.L., Marcus J.L., Fakra S.C., Devonshire J., McGrath.P., Quinn C.F., PilonSmits E.A. Selenium Hyperaccumulator Plants Stanleya pinnata and Astragalus bisulcatus Are Colonized by Se-Resistant, Se-Excluding Wasp and Beetle Seed Herbivores, PLOS ONE 2012; 7(12): e50516.

[30] Fernando E.S., Quimado M.O., Doronila A.I. Rinorea niccolifera (Violaceae), A New, Nickle-Hyperaccumlating Species from Luzon Iland, Philippines. PhytoKey 2014; 37: $1-13$.

[31] Van der Ent A. Discovery of Nickel Hyperaccumulators from Kinabalu Park, Sabah (Malaysia) for Potential Utilization in Phytomining. Conference Paper 2013, Santiago, Chile. http://www.researchgate.net/publication/259391966

[32] Future Miners Could Harvest Metal from Plants. University of Quweenland, QN News. http://www.uq.edu.au/news/article/2014/09/future-miners-could- harvestmetal-plants

[33] Huang J.W., Cunningham S.D. Lead Phytoextraction: Species Variation in Lead Uptake and Translocation. New Phytologist 1996; 134: 75-84.

[34] Bada B.S., Kalejaiye S.T. Response of Kenaf (Hibiscus Cannabinus L.) Grown in Different Soil Textures and Lead Concentrations. Research Journal of Agriculture and Biolgical Sciences 2010; 6(5): 659-664.

[35] Usha R., Vasavi A., Thishya K., Rani S.J., Spraja P. Phytoextraction of Lead from Industrial Effluents by Sunflower (Helianthus annuus. L). RASATAN Journal of Chemistry $2011 ; 4(1): 8-12$.

[36] Girdhar M., Sharma N.R., Rehman H., Kumar A., Mohan A. Comparative Assessment for Hyperaccumulatory and Phytoremediation Capability of Three Wild Weeds. 3 Biotech 2014; 4(6): 579-589. 
[37] Kos B., Grěman H., Leštan D. Phytoextraction of Lead, Zinc and Cadmium from Soil by Selected Plants. Plant Soil Envirnment 2003; 49(12): 548-553.

[38] Mkumbo S., Mwegoha W., Renman G. Assessment of the Phytoremediation Potential for $\mathrm{Pb}, \mathrm{Zn}$ and $\mathrm{Cu}$ of Indigenous Plants Growing in a Gold mining area in Tanzania. International Journal of Environmental Sciences 2012; 2(4): 2425-2434.

[39] Shen Z.G., Li X.D., Wang C.C., Chen H.M., Chua H. Lead Phytoextraction from Contaminated Soil with High-Biomass Plant Species. Journal of Environmental Quality 2002; 31(6): 1893-1900.

[40] Jiang W., Liu D., Hu W. Hyperaccumulation of Lead by Roots, Hypocotyls, and Shoots of Brassica juncea. Biologia Plantarum 2000; 43(4): 603-606.

[41] Mahdavi A., Khermandar K., Asbchin S.A., Tabaraki R. Lead Accumulation Potential in Acacia victoria. International Journal of Phytoremediation 2014; 16(6): 582-592.

[42] Tamura H., Honda M., Sato T., Kamachi H. Pb Hyperaccumulatin and Tolerance in Common Buckwheat (Fagopyrum esculentum Moench). Journal of Plant Research 2005; 118: 355-359.

[43] Kamachi H., Komori I., Tamura H., Sawa Y., Karahara I., Honma Y., Wada N., Kawabata T., Matsuda K., Ikeno S., Noguchi M., Inoue H. Lead Tolerance and Accumulation in the Gametophytes of the Fern Athyrium yokoscense. Journal of Plant Research 2005; 118(2): 137-145.

[44] Soongsombat P., Kruatrachue M., Chaiyarat R., Pokethitiyoook P., Negernsansaruay C. Lead Tolerance and Accumulation in Pteris vittata and Pityrogramma calomelanos and Their Potential for Phytoremediation of Lead-Contaminated Soil. Interational Journal of Phytoremdiaytion 2009; 11(4): 396-412.

[45] Basile A., Cogoni A.E., Bassi P., Fabrizi E., Sorbo S., Giordano S., Cobianchi R.C. Accumulation of $\mathrm{Pb}$ and $\mathrm{Zn}$ in Gametophytes and Sporophytes of the Moss Funaria hygrometrica (Funariales). Annals of Botany 2001; 87: 537-543.

[46] Krzesłowska M., Lenartowska M., Samardakiewicz S., Bilski H., Woźny A. Lead Deposited in the Cell Wall of Funaria Hygrometrica Protonemata Is Not Stable- A Remobilization Can Occur. Environtal Pollution 2010; 158(1): 325-338.

[47] Ito M., Honma Y., Nakatsuka S., Komatu Y., Kawakami S., Sakakibara H. Aqueous Environment Conservation and Metal-Resource Recycling Technology Using the Moss Funaria hygrometrica. Regulation of Plant Growth \& Development 2010; 45(1): 64-72.

[48] Wang Y., Tao J., Dai J. Lead Tolerance and Detoxification Mechanism of Chlorophytum comosum. African Journal of Biotechnology 2011; 10(65): 14516-14526. 
[49] Arshad M., Silvestre J., Pinelli E., Kallerhoff J., Kaemmerer M., Tarigo A., Shahid M., Guiresse M., Pradere P., Dumat C. A Field Study of Lead Phytoextraction by Various Scented Pelargonium Cultivars. Chemosphere 2008; 71(11): 2187-2192.

[50] Pulford I.D., Watson C. Phytoremediation of Heavy Metal-Contaminated Land by Trees -A Review. Environment International 2003; 29: 529-540.

[51] Liu W., Ni J., Zhou Q. Uptake of Heavy Metals by Trees: Prospects for Phytoremediation. Materials Science Forum 2013; 743-744: 768-781.

[52] Ismail S., Khan F., Iqbal M.Z. Phytoremediation: Assessing Tolerance of Tree Species Against Heavy Metal (PB and CD) Toxicity. Pakistan Journal of Botany 2013; 45(6): 2181-2186.

[53] Malá J., Máchová P., Cvrčková H., Vanék T. Heavy Metals Uptake by the Hybrid Aspen and Rowan-Tree Clones. Journal of Forest Science 2007; 53(11): 491-497.

[54] Chinweuba A.J., Otuokere I.E. Phyto Extraction of Lead from Lead Contaminated Soil Using Ixora coceinea and Ficus benjamina. 2nd International Conference on Chemical, Enviromental and Biological Sciences 2013 March17-18, Dubai (UAE).

[55] Kabir M., Iqbal M.Z., Shafiq M., Faroqi Z.R. Effects of Lead Seeding Growth of Thespesia ppulnea L. Plant Soil Environment 2010; 56(4): 194-199.

[56] Ang L.H., Tang L.K., Ho W.M., Hui T.F., Theseira G.W. Phytoremediation of Cd and $\mathrm{Pb}$ by Four Tropical Timber Species Grown on an Ex-tin Mine in Peninsular Malasia. International Journal of Environmental, Ecological, Geological and Mining Engineering 2010; 4(2): 13-17.

[57] Meeinkuirt W., Pokethitiyook P., Kruatrachue M., Tanhan P., Chaiyarat R. Phytostabilization of a Pb-Contaminated Mine Tailing by Various Tree Species in Pot and Field Trial Experiments. International Journal of Phytoremediation 2012; 14(9): 925-938.

[58] Itoh Y., Noguchi K., Takahashi M., Okamoto T., Yoshinaga S. Estimation of Lead Surces in a Japanese Cedar Ecosystem Using Stable Isotope Analysis. Applied Geochemistry 2007; 22(6): 1223-1228.

[59] A Table of Solubility. Wikipedia Japan. http://ja.wikipedia.org/wiki/

[60] Shimada N. The Essence of Problems on Groundwater and Soil Pollutions Caused by Naturally Occurring Heavy Metals and Harmful Elements: Lead. Oyo Technical Report 2013; 32: 1-27.

[61] Liu Y., Kobayashi T., Kameya T., Takahashi Y., Ohashi Y. Similation of Adsorption Equilibrium of Heavy Metal Cations on Soils in Circumneutral Aqeos Solutioon: Influences of Solution $\mathrm{pH}$ and Dissolved Humus Substances. Advanced Materials Research 2011; 289-290: 2822-2825. 
[62] Chaney R.L., Angle J.S., Broadhurst C.L., Peters C.A., Tappero R.V., Sparks D.L. Improved Understanding of Hyperaccumulatin Yields Commercial Phytoextracxtion and Phytomining Technologies. Journal of Environmental Qality 2007; 35: 1429-1443.

[63] Koyama K., Tanaka M. Removal of Lead by an Electrolytic Method from Aques Solutions Containing EDTA. Report of C.I.T. 2014; 61: 31-35.

[64] Voglar D., Lestan D. Chelant Soil-Washing Technology for Metal-Contaminated Soil. Environmental Technology 2014; 35(9-12): 1389-13400.

[65] Voglar D., Lestan D. Pilot-Scale Washing of $\mathrm{Pb}, \mathrm{Zn}$ and Cd Contaminated Soil Using EDTA and Process Water Recycling. Chemosphere 2013; 91(1): 76-82.

[66] Ebrahimi M., Shahsavand F. EDTA Enhanced Phytoremediation Capacity of Scripus maritimus L. Grown on Pb-Cr Contaminated Soil and Associated Potential Leaching Risks. Internatinal Journal of Scientific Research in Enviromental Sciences 2014; 2(10): 379-388.

[67] Huang J.W., Chen J., Berti W.R., Cunningham S.D. Phytoremediation of Lead-Contaminated Soils: Role of Synthetic Chelates in Lead Phytoextraction. Environmental Science \& Technology 1997; 31(3): 800-805.

[68] Watanabe K., Ono Y. Effect of Ethylene Diamine Tetraacetic Acid on Pb Phytoremediation by Using Brassica juncea and Pelafornium aonale. Bullten in Teikyo University of Science 2005; 1: 67-71.

[69] Tamura H., Umeda I., Honda M., Hibino Y., Sato K. Abstract of Meeting in Japanese Society of Soil Science and Plant Nutrition 2004; 50: 175. http://repository.lib.gifu-.ac.jp/handle/123456789/27696

[70] Yuan Z., VanBriesen J.M. The Formation of Intermediates in EDTA and NTA Biodegradation. Environmental Engineering Science 2006; 23 (3): 533-544.

[71] Tsang D.C.W., Yip T.C.M., Lo I.M.C. Kinetic Interactions of EDDS with Soils. 2. Metal-EDDS Complexes in Uncontaminated and Metal-Contaminated Soils. Environmental Science and Technology 2009; 43(3): 837-842.

[72] Wang X., Wang Y., Mahmood Q., Islam E., Jin X, Li T., Yang X., Liu D. The Effect of EDDS Addition on the Phytoextraction Efficiency from Pb Contaminaed Soil by Sedium Alfredii Hance. Journal of Hazardus Materials 2009; 168: 530-535.

[73] Yip T.C.M., Tsang D.C.W., Ng K.T.W., Lo I.M.C. Empirical Modeling of Heavy Metal Extraction by EDDS from Single-Metal and Multi-Metal Contaminated Soils. Chemosphere 2009; 74(2): 301-307.

[74] Nowback B., Schulin R., Robinson B.H. Critical Assessment of Chelant-Enhanced Metal Phytoextraction. Journal of Environmental Science \& Technology 2006; 40: $5525-5532$. 
[75] Zhou D.M., Chen H.F., Chang L., Wang Y.J. Regrass Uptake of Soil Cu/Zn Induced by EDTA/EDDS Together with a Vertical Direct-Current Electrical Field. Chemosphere 2007; 67(8): 1671-1678.

[76] Falglia P.P., Vagliasindi F.G.A. Enhanced Phytoextraction of Lead by Indian Mustard Using Electric Field. Chemical Engineering Transactions 2013; 32: 379-384.

[77] Bi R., Schlaak M., Siefert E., Lord R., Connolly H. Influence of Electrical Fields (AC and DC) on Phytoremediation of Metal Polluted Soils with Rapeseed (Brassica napus) and Tobacco (Nicotiana tabacum). Chemosphere 2011; 83(3): 318-326.

[78] Chibuke G.U., Obira S.C. Heavy Metal Polluted Soils: Effects on Plants and Bioremediation Methods. Applied Environmental Soil Science 2014; Article ID 752708.

[79] Kunito T., Matsumoto S., Ecology of Heavy Metal-Resistant Microorganisms in Soil and Their Use in Remediation of Contaminated Soils. AIRIES 2010; 37-41.

[80] Cao X., Ma L.Q., Rhue D.R. Appel CS. Mechanisms of Lead, Copper, and Zinc Retention by Phosphate Rock. Environmental Pollution 2004; 131(3): 435-444.

[81] Topcuoğlu B. Effects of Humic Acids on the Phytoextraction Efficiency of Sludge Applied Soil. International of Chemical, Environmental \& Biological Sciences 2013; 1(1): $21-24$

[82] Debela F., Arocena J.M., Thring R.W., Whitcombe T. Organic Acid-Induced Release of Lead from Pyromorphite and its Relevance to Reclamation of Pb-Contaminated Soils. Chemosphere 2010; 80(4): 450-456.

[83] Hadi F., Hussain F., Hussain M., Sanullah, Ahmad A., Ur Rahman S., Ali N. Phytoextraction of $\mathrm{Pb}$ and $\mathrm{Cd}$; the Effect of Urea and EDTA on Cannabis sativa Growth Under Metals Stress. International Journal of Agronomy and Agricultural Research 2014; 5(3): 30-39.

[84] Amoakwah E., Ampofo-Asiama J., Slycken S.V., Essumang D.K. A Comparison of the Solubilizing Potential of Some Aminopolycarboxylic Acids, Hortrilon ${ }^{\circledR}$ and Fetrilon® for Use in Phytoextraction. Open Journal of Soil Science 2013; 3: 182-190.

[85] Chen K.F., Yeh T.Y., Lin C.F. Phytoextraction of Cu, Zn, and Pb Enhanced by Chelators with Vetiver (Vetiveria zizanioides): Hydroponic and Pot Experiments 2012; Article ID 729693.

[86] Whiting S.N., de Souza M.P., Terry N. Rhizosphere Bacteria Mobilize Zn for Hyperaccumulation by Thlaspi caerulescens. Environmental Science \& Technology 2001; 35(15): 3144-3150.

[87] Gamalero E., Lingua G., Berta G., Glick B.R. Beneficial Role of Plant Growth Promoting Bacteria and Arbuscular Mycorrhizal Fungi on Plant Responses to Heavy Metal Stress. Canadian Journal of Microbiology 2009; 55(5): 501-514. 
[88] Wani P.A., Khan M.S. Bioremediation of Lead by a Plant Growth Promoting Rhizobium Species RL9. Bacteriology Journal 2012; 2(4): 66-78.

[89] Pilon-Smits E., Pilon M. Phytoremediation of Metals Using Transgenic Plants. Critical Reviews in Plant Sciences 2002; 21(5): 439-456.

[90] Celso de Mello- Farias P., Chaves A.L.S., Lencina C.L. Transgenic Plants for Enhanced Phytoremediation. In: María Alvarez (ed) Physiological Studies. Genetic Transformation. Rijeka: InTech; 2011. p305-328.

[91] Verbruggen N., LeDue D. Potential of Plant Genetic Engineering for Phytoremediation of Toxic Trace Elements. Encyclopedia of Life Spport System (ELOSS). http:// www.eolss.net/Sample-Chapters/C09/E6-199-12-00

[92] Fulekar M.H., Singh A., Bhaduri A.M. Genetic Engineering for Enhancing Phtytoremediation of Heavy Metals. African Journal of Biotechnology 2009: 8(4): 529-535.

[93] Van Huysen T., Abdel-Ghany S., Hale K.L., LeDuc D., Terry N., Pilon-Smits E.A. Overexpression of Cystathionine-Gamma-Synthase Enhances Selenium Volatilization in Brassica juncea. Planta. 2003; 218(1): 71-78.

[94] Kotrba P., Najmanova J., Macek T., Ruml T., Mackova M. Genetically Modified Plants in Phytoremediation of Heavy Metal and Metalloid Soil and Sediment Pollution. Biotechnology Advances 2009; 27(6): 799-810.

[95] Bizily S.P., Kim T., Kandasamy M.K., Meagher R.B. Subcellular Targeting of Methylmercury Lyase Enhances Its Specific Activity for Organic Mercury Detoxification in Plants. Plant Physiology 2003; 131(2): 463-471.

[96] Bañuelos G., Terry N., LeDuc D.L., Pilon-Smits E.A.H, Mackey B. Field Trial of Transgenic Indian Mustard Plants Shows Enhanced Phytoremediation of SeleniumContaminated Sediment. Environmental Science \& Technology 2005; 39(6): 1771-1777.

[97] Xin X., S-Yuan T. Lin H. Remediation of Heavy Metal Contaminated Soil by Transgenic Plants. Chinese Bulletin of Botany 2004; 21(5): 595-607.

[98] Kim D.Y., Bovet L., Maeshima M., Martinoia E., Lee Y. The ABC Transporter AtPDR8 Is a Cadmium Extrusion Pump Conferring Heavy Metal Resistance. Plant Journal 2007; 50(2): 207-218.

[99] Kim D.Y., Bovet L., Kushnir S., Noh E.W., Martinoia E., Lee Y. AtATM3 Is Involved in Heavy Metal Resistance in Arabidopsis. Plant Physiology 2006; 140(3): 922-932.

[100] Arazi T., Sunkar R., Kaplan B., Fromm H. A Tobacco Plasma Membrane CalmodulinBinding Transporter Confers Ni2+ Tolerance and $\mathrm{Pb}^{+}$Hypersensitivity in Transgenic Plants. The Plant Journal 1999; 20(2): 171-182.

[101] Lee J., Bae H., Jeong J., Lee J.Y., Yang Y.Y., Hwang I., Martinoia E., Lee Y. Functional Expression of a Bacterial Heavy Metal Transporter in Arabidopsis Enhances Resist- 
ance to and Decreases Uptake of Heavy Metals. Plant Physiology 2005; 139(2): 589-596.

[102] Song W.Y., Sohn E.J., Martinoia E., Lee Y.J., Yang Y.Y., Jasinski M., Forestier C., Hwang I., Lee Y. Engineering Tolerance and Accumulation of Lead and Cadmium in Transgenic Plants. Nature Biotechnology 2003; 21(8): 914-919.

[103] Shim D., Kim S., Choi Y.I., Song W.Y., Park J., Youk E.S., Jeong S.C., Martinoia E., Noh E.W., Lee Y. Transgenic Poplar Trees Expressing Yeast Cadmium Factor 1 Exhibit the Characteristics Necessary for the Phytoremediation of Mine Tailing Soil. Chemosphere 2013; 90(4): 1478-1486.

[104] Glass D.J. Phytoremediation's Economic Potential In: Raskin I. and Ensley B.D. (ed) Phytoremediation of Toxic Metals: Using Plants to Clean Up the Environment. New York: Willy; 1999. p15-31.

[105] Mkumbo S., Mwegoha W., Renman G. Assessment of the Phytoremediation for Pb, Zn and Cd of Indigenos Plants Growing in a Gold Mining Are in Tanzania. International Journal of Environmental Sciences 2012; 2(4): 2425-2434.

[106] Park J.H., Bolan N., Megharaj M., Naidu R., Cheng J.W. Bacterial-Assisted Immobilization of Lead in Soil Implications for Remediation. Pedologist 2011; 162-174.

[107] Jarosławiecka A., Piotrowska-Seget Z. Lead Resistance in Micro-Organisms. Microbiology 2014; 160(1): 12-25.

[108] Perpetuo E.A., Souza C.B., Nascimento C.A.O. Engineering Bacteria for Bioremediation. In: Angelo Carpi (ed) Progress in Molecular and Environmental Bioengineering - From Analysis and Modeling to Technology Applications. Rijeka: InTech; 2011. p605-632.

[109] Amoozegar M.A., Ghazanfari N., Didari M. Lead and Cadimium Bioremoval by Halomonas sp., an Exopolysaccharide-Producing Halophilic Bacterium. Progress in Biological Sciences 2012; 2(1): 1-11.

[110] Freire-Nordi C.S., Vieira A.A.H., Nakaie C.R., Nascimento O.R. Effect of Polysaccharide Capsule of the Microalgae Staurastrum iversenii var. americanum on Diffusion of Charged and Uncharged Molecules, Using EPR Technique. Brazilian Journal of Physics 2006; 36(1): 75-82.

[111] Selehizadeh H., Shiojaosadati S.A. Removal of metal ions from aqueous solution by polysaccharide produced from Bacillus firmus. Water Research 2003; 37(17): 4231-4235.

[112] Morillo J.A., Aguilera M., Ramos-Cormenzana A., Monteoliva-Sánchez M. Production of A Metal-Binding Exopolysaccharide by Paenibacillus jamilae Using Two-Phase Olive-Mill Waste as Fermentation Substrate. Current Microbiology 2006; 53(3): 189-193. 
[113] Cabuk A., Akar T., Tunali S., Tabak O. Biosorption Characteristics of Bacillus sp. ATS-2 Immobilized in Silica Gel for Removal of $\mathrm{Pb}(\mathrm{II})$. Journal of Hazardous Materials 2006; 136(2): 317-323.

[114] Gabra R.M., Hassanb S.H.A., Shoreit A.A.M. Biosorption of Lead and Nickel by Living and Non-Living Cells of Pseudomonas aeruginosa ASU 6a. International Biodeterioration \& Biodegradation 2008; 62(2): 195-203.

[115] Li S., Jin-lan X.I.A, Huan H.E., Zhen-yuan N.I.E. Comparative Study on Biosorption of $\mathrm{Pb}(\mathrm{II})$ and $\mathrm{Cr}(\mathrm{VI})$ by Synechococcus sp. Transactions of Nonfererrous Metals Society of China 2008; 18(6): 1336-1342.

[116] Ozer A., Ozer D. Comparative Study of the Biosorption of $\mathrm{Pb}(\mathrm{II}), \mathrm{Ni}(\mathrm{II})$ and $\mathrm{Cr}(\mathrm{VI})$ Ions onto S. cerevisiae: Determination of Biosorption Heats. Journal of Hazardous Materials 2003; 100(1-3): 219-29.

[117] Akar T., Tnali S. Biosorption Characteristics of Aspergillus flavus Biomass for Removal of $\mathrm{Pb}(\mathrm{II})$ and $\mathrm{Cu}(\mathrm{II})$ Ions from an Aqueous Solution. Bioresource Technology 2006; 97(15): 1780-1787.

[118] Taboski M.A., Rand T.G., Piórko A. Lead and Cadmium Uptake in the Marine Fungi Corollospora lacera and Monodictys pelagica. FEMS Microbiology Ecolgy 2005; 53(3): 445-453.

[119] Murthy S., Bali G., Sarangi S.K. Effect of Lead on Metallothionein Concentration in Lead Resistant Bacteria Bacillus cereus Isolated from Industrial Effluent. African Journal of Biotechnology 2011; 10(71): 15966-15972.

[120] Rifaar H.M., Mahrous K.F., Khalil W.K.B. Effect of Heavy Metals upon Metallochioneines in Some Streptomyces Species Isolated from Egyptian Soil. Journal of Applied Sciences in Environmental Sanitation 2009; 4: 197-206.

[121] Braud A., Geoffroy V., Hoegy F., Mislin G.L., Schalk I.J. Presence of the Siderophores Pyoverdine and Pyochelin in the Extracellular Medium Reduces Toxic Metal Accumulation in Pseudomonas aeruginosa and Increases Bacterial Metal Tolerance. Environmental Microbiology 2010; 2(3): 419-425.

[122] Tripathi M., Munot H.P., Shouche Y., Meyer J.M., Goel R. Isolation and Functional Characterization of Siderophore-Producing Lead- and Cadmium-Resistant Pseudomonas putida KNP9. Current Microbiology 2005; 50(5): 233-237.

[123] Braud A., Geoffroy V., Hoegy F., Mislin G.L., Schalk I.J. Presence of the Siderophores Pyoverdine and Pyochelin in the Extracellular Medium Reduces Toxic Metal Accumulation in Pseudomonas aeruginosa and Increases Bacterial Metal Tolerance. Environmental Microbiology 2010; 2(3): 419-425.

[124] Levinsona H.S., Mahler I., Blackwelderb P., Hoodb T. Lead Resistance and Sensitivity in Staphylococcus aureus. FEMS Microbiology Letters 1996; 145(3): 421-425. 
[125] Mire C.E., Tourjee J.A, O'Brien W.F., Ramanujachary K.V., Hecht G.B. Lead Precipitation by Vibrio harveyi: Evidence for Novel Quorum-Sensing Interactions. Applied and Environmental Microbiology 2004; 70(2): 855-864.

[126] Park J., Bolan N., Megharai M., Naidu R. Isolation of Phosphate-Sollubiilizing Bacteria and Characterization of Their Effects on Lead Immobilization. Pedlogist 2010; 53: 67-75.

[127] Weijma J., De Hoop K., Bosma W., Dijkman H. Biological Conversion of Anglesite $(\mathrm{PbSO}(4))$ and Lead Waste from Spent Car Batteries to Galena (PbS). Biotechnology Progress 2002; 18(4): 770-775.

[128] Kang S.H., Singh S., Kim J.Y., Lee W., Mulchandani A., Chen W. Bacteria Metabolically Engineered for Enhanced Phytochelatin Production and Cadmium Accumulation. Applied Environmental Microbiology 2007; 73(19): 6317-6320.

[129] Yong X., Chen Y., Liu W., Xu L., Zhou J., Wang S., Chen P., Ouyang P., Zheng T. Enhanced Cadmium Resistance and Accumulation in Pseudomonas putida KT2440 Expressing the Phytochelatin Synthase Gene of Schizosaccharomyces pombe. Letters in Applied Microbiology 2014; 58(3): 255-261.

[130] Datta B., Chakrabartty P.K. Siderophore Biosynthesis Genes of Rhizobium sp. Isolated from Cicer arietinum L. 3 Biotech 2014; 4(4): 391-401.

[131] Rossbach S., Wilson T.L., Kukuk M.L., Carty H.A. Elevated Zinc Induces Siderophore Biosynthesis Genes and a ZntA-Like Gene in Pseudomonas fluorescens. FEMS Microbiology Letters 2000; 191(1): 61-70. 